\title{
Effect of Dynamic Soil-Structure Interaction on Raft of Piled Raft Foundation of Chimneys
}

\author{
B. R. Jayalekshmi, S. V. Jisha, R. Shivashankar, and S. Soorya Narayana \\ Department of Civil Engineering, National Institute of Technology Karnataka, Surathkal, Mangalore 575025, India \\ Correspondence should be addressed to S. V. Jisha; jpn.nitk@gmail.com
}

Received 30 September 2013; Accepted 5 December 2013; Published 20 January 2014

Academic Editors: D. Huang, G. Li, J. Wang, and D. Zeng

Copyright (C) 2014 B. R. Jayalekshmi et al. This is an open access article distributed under the Creative Commons Attribution License, which permits unrestricted use, distribution, and reproduction in any medium, provided the original work is properly cited.

\begin{abstract}
This paper presents numerical analysis of soil-structure-interaction (SSI) of tall reinforced concrete chimneys with piled raft foundation subjected to El Centro ground motion (1940) using finite element method. Seismic analysis in time domain was performed on the basis of direct method of SSI on the three-dimensional SSI system. The chimney, foundation, and soil were assumed to be linearly elastic in the analysis. The stress resultants and settlement of raft of piled raft foundation were evaluated under different soil properties and different geometrical features of raft and chimney. Soil properties were selected based on the shear wave velocity corresponding to sand in the loose to dense range. Chimneys with different elevations of $100 \mathrm{~m}, 200 \mathrm{~m}$, and $400 \mathrm{~m}$ were taken with a ratio of height to base diameter of chimney of 17. Raft of different thickness was considered to evaluate the effect of stiffness of foundation. Results were analysed to assess the significance of characteristic of the ground motion. It is found that the response in the raft depends on the different parameters of chimney, foundation, and soil. It is also found that the higher modes of SSI system are significant in determining the response in the raft.
\end{abstract}

\section{Introduction}

Most of the analysis of piled raft foundation neglects the effect of geometrical and material features of the superstructure. Generally the loads and moments from the superstructure to foundation are only considered for the analysis of foundation. The shape and size of the superstructure such as chimney have their own significance to determine the responses in foundation. Chimneys are tall and slender structures with tapering geometry. Analysis of such kind of chimneyfoundation system that rests on soil which is of unfavorable geotechnical conditions will be too complex especially when it is subjected to earthquake ground motions. The present study deals with the seismic analysis of chimney with piled raft foundation considering the flexibility of soil in time domain.

\section{Background of the Problem}

Very few studies have been carried out in the area of dynamic analysis of soil-piled raft-structure interaction compared to that of soil-pile-structure interaction [1-3]. Field measurements were taken by Yamashita et al. [4] to understand the static and seismic behavior of a piled raft foundation which is supporting a 12-story base-isolated building in Tokyo from the beginning of the construction to 43 months after the end of the construction. During the monitoring period of the building, Tohoku Earthquake (2011) struck the building site. From the above study, it was found that the horizontal accelerations of the superstructure were reduced to approximately $30 \%$ of those of the ground near the ground surface by the input losses due to the kinematic soil-foundation interaction in addition to the base isolation system. This study pointed out the relevance of detailed analysis of soil-foundation-structure system under seismic ground motions. The load sharing between the raft and the pile was studied by many researchers [5-7]. An approximate analysis for piled raft foundations for the vertical load was carried out by Ta and Small [8]. It is observed that most of the recent literatures [9-15] concentrated on the study of piled raft foundations under vertical loads only. Chaudhary [16] investigated the effectiveness of pile foundation in reducing 
settlement by comparing the results of piled raft foundation and the raft foundation alone. The effect of the superstructure is not considered in these piled raft studies.

The two basic methods involved in the solution of soil-structure interaction (SSI) problems are referred to as the direct method and substructure method. Wolf [17] clearly described these basic methods. The entire structurefoundation-soil system is modeled and analyzed in a single step as per the direct method of SSI. One of the main advantages in this method is that it can be easily implemented using a finite element platform. The nonlinear material laws of the soil can be taken into account using this method. Many recent studies [18-20] utilised this method for the SSI analysis of complex structures using the powerful computing efficiency in most modern computers. In substructure approach, the soil-structure system is divided into two substructures, the soil medium and the structures. This method is based on the principle of superposition. One of the drawbacks in this method is that only linear systems can be analysed $[21,22]$.

Very few studies were conducted for the static and dynamic SSI analysis of chimney-foundation system. The distribution of bending moments and shear force along the height of chimneys due to earthquake ground motion considering the soil flexibility was studied by Arya and Paul [23]. In the above study, the chimney was idealized by lumped-mass model, and soil below chimney-raft system was idealized by equivalent linear elastic translational and rotational springs and dashpots. A semianalytic mathematical model was proposed by Pour and Chowdhury [24] which was based on both seismic and aerodynamic response of tall chimneys for various soil stiffness and was compared with the fixed base conventional method. It was found that the SSI effects were reliant on the characteristic of the seismic excitation in addition to chimney properties. The effect of long duration earthquakes in a $215 \mathrm{~m}$ tall chimney with annular raft foundation considering SSI was studied by Mehta and Gandhi, [25] using finite element technique. From the above study it was concluded that the time period increases up to $9 \%$ for soft soil in fundamental mode and up to $80-85 \%$ for higher modes. All the above studies observed the response of chimney due to soil flexibility. The effect of SSI on the annular raft foundation of tall RC chimneys subjected to along-wind load was studied by Jayalekshmi et al. [26] and it was found that, due to the effect of flexibility of supporting soil, there is a considerable reduction in the bending moments in the annular raft foundation.

The annular raft foundations are more reasonable and economical than the full circular raft for industrial chimneys. If the geotechnical conditions are not favorable for raft foundations, piled foundations can also be used. Skinfriction piles are more suitable to chimney foundations than end-bearing piles, since greater uplift capacity is generally available [27]. Very limited studies concentrated on the seismic analysis of chimney-piled raft-soil system. Therefore, the present study focuses on the three-dimensional SSI analysis of chimney with piled raft foundation subjected to El Centro (1940) earthquake ground motion in time domain. Finite element method is utilized for the evaluation of stress resultants and settlements of the raft of piled raft foundation.
The results obtained from finite element analysis are compared with that obtained from the conventional analysis of annular raft foundation as per Indian standard code IS:110891984 [28].

\section{Analysis of Annular Raft Foundation as per IS:11089-1984}

The basic assumptions of conventional method of analysis of annular raft foundation given in IS:11089-1984 [28] are as follows. (i) The foundation is rigid relative to the supporting soil and the compressible soil layers which are relatively shallow. (ii) The contact pressure distribution is assumed to vary linearly throughout the foundation. The cross-sectional elevation and plan of chimney with annular raft foundation and the pressure distribution under annular raft are given in Figure 1. As per IS:11089-1984 [28], the nonuniform pressure distribution under annular raft is modified to uniform pressure distribution $p$, equivalent to $p_{1}+0.5 p_{2}$, where $p_{1}$ is uniform pressure due to dead loads $(V)$ and $p_{2}$ is pressure due to bending effects $(M)$ as shown in Figure 1. The formulae for circumferential and radial moments $M_{t}$ and $M_{r}$, respectively, are given in Figure 1:

For $r<c$,

$$
\begin{gathered}
M_{t}=\frac{p a^{2}}{16}\left[\left\{4\left(1+\frac{b^{2}}{r^{2}}\right)\left(\log _{e} \frac{a}{c}+\frac{1}{2}-\frac{c^{2}}{2 a^{2}}\right)\right\}\right. \\
+\frac{r^{2}}{a^{2}}-\frac{4 b^{2}}{a^{2}}\left\{\log _{e} \frac{r}{a}+\frac{3}{4}\left(\frac{1}{3}+\frac{a^{2}}{b^{2}}+\frac{a^{2}}{r^{2}}\right)\right. \\
\left.\left.-\frac{a^{2}+r^{2}}{a^{2}-b^{2}} \cdot \frac{b^{2}}{r^{2}} \log _{e} \frac{a}{b}\right\}\right], \\
M_{r}=\frac{p a^{2}}{16}\left[\left\{4\left(1-\frac{b^{2}}{r^{2}}\right)\left(\log _{e} \frac{a}{c}+\frac{1}{2}-\frac{c^{2}}{2 a^{2}}\right)\right\}\right. \\
+\frac{3 r^{2}}{a^{2}}-\frac{4 b^{2}}{a^{2}}\left\{\log _{e} \frac{r}{a}+\frac{3}{4}\left(1+\frac{a^{2}}{b^{2}}-\frac{a^{2}}{r^{2}}\right)\right. \\
\left.\left.+\frac{a^{2}-r^{2}}{a^{2}-b^{2}} \cdot \frac{b^{2}}{r^{2}} \log _{e} \frac{a}{b}\right\}\right] .
\end{gathered}
$$

For $r>c$,

$$
\begin{aligned}
& M_{t}=\left(M_{t}\right)_{r<c}+\frac{p a^{2}}{16}\left[4\left(1-\frac{b^{2}}{a^{2}}\right)\left(\log _{e} \frac{c}{r}+\frac{1}{2}-\frac{c^{2}}{2 r^{2}}\right)\right], \\
& M_{r}=\left(M_{r}\right)_{r<c}+\frac{p a^{2}}{16}\left[4\left(1-\frac{b^{2}}{a^{2}}\right)\left(\log _{e} \frac{c}{r}-\frac{1}{2}+\frac{c^{2}}{2 r^{2}}\right)\right],
\end{aligned}
$$

where $a$ and $b$ are the outer and inner radius of annular raft respectively, $r$ is the radial distance, and $c$ is the radius of chimney windshield at base. 


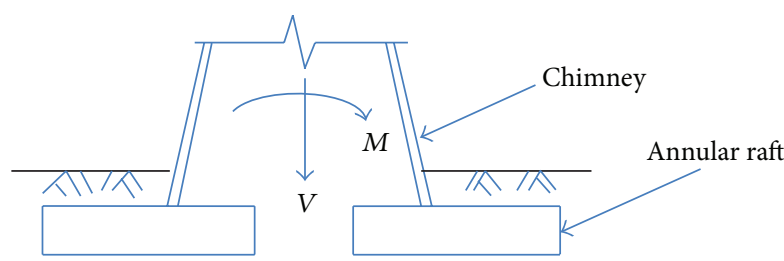

(a)

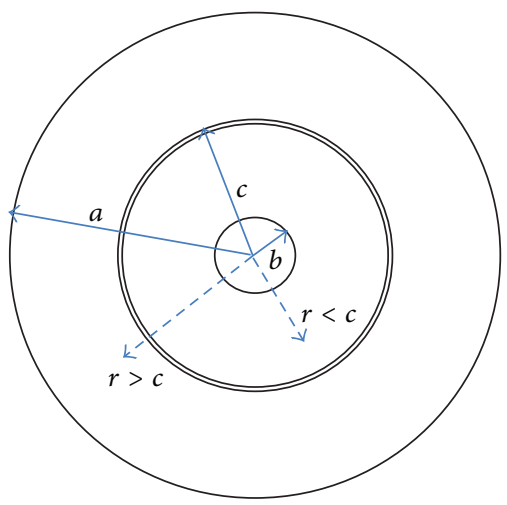

(b)
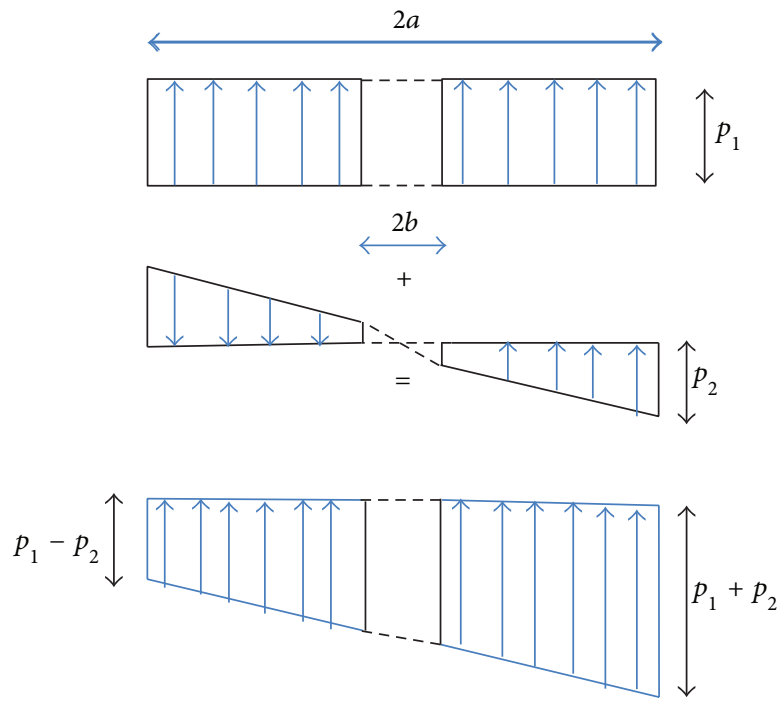

(c)

FIGURE 1: (a) Cross-sectional elevation of chimney and annular raft foundation, (b) plan view of chimney and annular raft foundation, and (c) pressure distribution under the annular raft due to dead weight and bending moment.

\section{SSI Analysis of Chimney with Piled Raft Foundation}

The finite element analysis was carried out based on direct method of SSI for the tall RC chimney with piled raft foundation founded on soil with different geotechnical properties. The geometrical properties of chimney and the foundation were also varied to study the effect of SSI. The integrated chimney-piled raft-soil system was analysed for El Centro (1940) ground motion in time domain. The stress resultants of the raft of piled raft foundation obtained from SSI analysis
TABLE 1: Geometric parameters of chimney.

\begin{tabular}{lcccc}
\hline$H(\mathrm{~m})$ & $D_{b}(\mathrm{~m})$ & $D_{t}(\mathrm{~m})$ & $T_{b}(\mathrm{~m})$ & $T_{t}(\mathrm{~m})$ \\
\hline 100 & 6 & 3.6 & 0.2 & 0.2 \\
200 & 12 & 7.2 & 0.35 & 0.2 \\
400 & 24 & 14.4 & 0.7 & 0.3 \\
\hline
\end{tabular}

$H$ : Height of chimney, $D_{b}$ : diameter at base of chimney, $D_{t}$ : diameter at top of chimney, $T_{b}$ : thickness at base of chimney, and $T_{t}$ : thickness at top of chimney.

were compared with that obtained from the conventional analysis considering rigidity at the base of the foundation. The settlement of raft is also studied due to the effect of SSI of chimney-piled raft system.

4.1. Idealization of Chimney. The tallest chimney in the world has more than $400 \mathrm{~m}$ height. Therefore, in this study, chimney elevations of $100 \mathrm{~m}, 200 \mathrm{~m}$, and $400 \mathrm{~m}$ were considered. Practical range of slenderness ratio (ratio of height to base diameter) of chimneys varies from 7 to 17 [29]. Slender chimneys with slenderness ratio of 17 were selected for the study. The taper ratio (ratio of top diameter to base diameter) and ratio of base diameter to thickness at bottom were considered as 0.6 and 35 , respectively. The thickness at top of chimney was taken as 0.4 times the thickness at bottom, but the minimum thickness at top was kept at $0.2 \mathrm{~m}$. All the above chimney parameters were selected based on the study conducted by Menon and Rao [29]. Details of different geometric parameters of chimney are given in Table 1. M30 grade concrete and Fe 415 grade steel were selected as the materials for chimney.

4.2. Idealization of Piled Raft Foundation. The chimney is supported by piled raft foundation. The raft of piled raft foundation was considered as annular with uniform thickness. The overall diameter of raft for a concrete chimney is typically $50 \%$ greater than the diameter of the chimney shaft at ground level [27]. The ratio of outer diameter to thickness $\left(D_{o} / t\right)$ of annular raft was taken as 12.5, 17.5, and 22.5 based on the study conducted by Jayalekshmi et al. [26]. RC friction piles of $20 \mathrm{~m}$ length $(l)$ and $1 \mathrm{~m}$ diameter were considered. For friction piles, the optimum spacing recommended is $3 d$ where $d$ is the diameter of the pile. Spacing (s) of $3 d$ ensures that interference of stress zones of adjacent friction piles is minimum and results in a high group efficiency. Therefore, s/d of 3 was selected for the present study. M30 grade concrete and $\mathrm{Fe} 415$ grade steel were selected as the materials for piled raft foundation. Table 2 gives the details of different geometric parameters of raft and the total number of piles.

4.3. Idealization of Soil Stratum. The soil is idealized by single homogeneous strata of $30 \mathrm{~m}$ depth beneath the foundation. To study the effect of SSI, the properties of the soil stratum were varied. For this, four types of dry cohesionless soil were selected and they are S1, S2, S3, and S4 which represent loose sand, medium sand, dense sand, and rock, respectively. The properties of the soil stratum were defined by its shear 
TABLE 2: Geometric parameters of piled raft foundation.

\begin{tabular}{lcccccc}
\hline$H(\mathrm{~m})$ & $D_{o}(\mathrm{~m})$ & $D_{i}(\mathrm{~m})$ & $D_{o} / t=12.5$ & $D_{o} / t=17.5$ & $D_{o} / t=22.5$ & 0.62 \\
\hline 100 & 14 & 4 & 1.12 & 0.8 & 1.2 & 18 \\
200 & 26 & 6 & 2.08 & 1.5 & 2.7 \\
400 & 60 & 8 & 4.8 & 3.4 & 311 \\
\hline
\end{tabular}

$D_{o}$ : External diameter of the raft, $D_{i}$ : internal diameter of the raft, and $t$ : thickness of the raft.

TABle 3: Properties of the soil types.

\begin{tabular}{lccccc}
\hline $\begin{array}{l}\text { Soil } \\
\text { types }\end{array}$ & $\begin{array}{c}\text { Shear wave } \\
\text { velocity } \\
V_{s}(\mathrm{~m} / \mathrm{sec})\end{array}$ & $\begin{array}{c}\text { Poisson's } \\
\text { ratio }\end{array}$ & $\begin{array}{c}\text { Density } \\
\left(\mathrm{kN} / \mathrm{m}^{3}\right)\end{array}$ & $\begin{array}{c}\text { Elastic } \\
\text { modulus } \\
E\left(\mathrm{kN} / \mathrm{m}^{2}\right)\end{array}$ & $\begin{array}{c}\text { Angle of } \\
\text { friction } \\
\left(^{\circ}\right)\end{array}$ \\
\hline S1 & 100 & 0.4 & 16 & 108,752 & 30 \\
S2 & 300 & 0.35 & 18 & 445,872 & 35 \\
S3 & 600 & 0.3 & 20 & $1,908,257$ & 40 \\
S4 & 1200 & 0.3 & 20 & $7,633,028$ & 45 \\
\hline
\end{tabular}

wave velocity, mass density, elastic modulus, and Poisson's ratio as per [30,31]. Coefficient of internal friction between the soil and the pile were taken as per Meyerhof given in the Foundation Engineering Handbook (Fang [32]). The properties of the soil stratum are given in Table 3.

4.4. Finite Element Modeling. The finite element modeling and seismic analysis were carried out using the finite element software, ANSYS. In the finite element modeling, SHELL63 elements were used to model the chimney and the raft of piled raft foundation. SHELL63 element is defined by four nodes having six degrees of freedom in each node. The threedimensional soil stratum and the pile were modeled with SOILD45 elements with eight nodes having three translational degrees of freedom at each node. The surface-surface contact elements were used to represent the interaction between pile and soil. The pile surface was established as "target" surface (TARGE170), and the soil surface contacting the pile as "contact" surface (CONTAC174); these two surfaces constitute the contact pair. The coefficient of friction was defined between contact and target surfaces and is shown in Table 3.

The chimney shell was discretised with element of $2 \mathrm{~m}$ size along height and with divisions of $7.5^{\circ}$ in the circumferential direction. Diameter and thickness of chimney were varied linearly along the entire height. The raft and soil strata were discretised with divisions of $7.5^{\circ}$ in the circumferential direction. Three-dimensional finite element model of the integrated $200 \mathrm{~m}$ high chimney-piled raft-soil system was generated using the ANSYS software and is shown in Figure 2. The finite element models of piled raft and that of a single pile are shown in Figure 3. Figure 4 shows the plan view of raft of piled raft foundation of $200 \mathrm{~m}$ chimney.

Linear elastic material behaviour was assumed for chimney, piled raft, and soil. M30 grade concrete was selected for chimney and foundation. The modulus of elasticity for chimney was taken as $33.5 \mathrm{Gpa}$ as per IS:4998 (Part1)-1992 [33] and that for foundation was taken as $27.39 \mathrm{Gpa}$. The

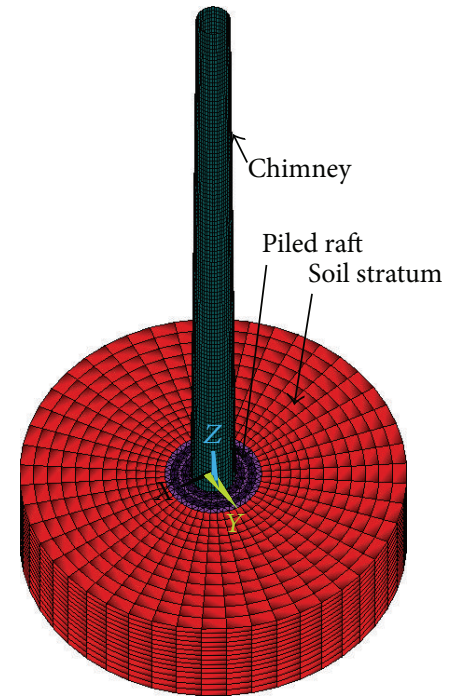

Figure 2: Finite element model of $200 \mathrm{~m}$ high chimney-piled raftsoil system.

Poisson's ratio and density of concrete were taken as 0.15 and $25 \mathrm{kN} / \mathrm{m}^{3}$, respectively, for both chimney and foundation.

Elastic continuum approach was adopted for modeling the soil. The material properties such as elastic modulus, Poisson's ratio, and density for the three-dimensional soil stratum were taken from Table 3 . Bedrock was assumed at a depth of $30 \mathrm{~m}$ below the soil stratum [19]. Therefore, all the movements of soil stratum were restrained at bed rock level. It is required to represent the unbounded domain of soil medium in the finite element platform. The soil lateral boundary was restricted at sufficient finite distance so that the waves propagated from the soil cannot reflect back. The soil up to four times the breadth of foundation on sideways was considered in the analysis and viscous boundaries were applied in the lateral boundaries using spring elements for simulating the effect of infinite soil medium. The equation of motion with additional damping matrix $C^{*}$ can be written as follows when the viscous boundaries are taken into account $[34,35]$ :

$$
[M]\{\ddot{u}(t)\}+[C]\{\dot{u}(t)\}+\left[C^{*}\right]\{\dot{u}(t)\}+[K]\{u(t)\}=\{P(t)\},
$$

where $C^{*}$ is the special damping matrix that may be considered as follows:

$$
\left[C^{*}\right]=\left[\begin{array}{ccc}
A_{n} \rho v_{p} & 0 & 0 \\
0 & A_{t 1} \rho v_{s} & 0 \\
0 & 0 & A_{t 2} \rho v_{s}
\end{array}\right],
$$




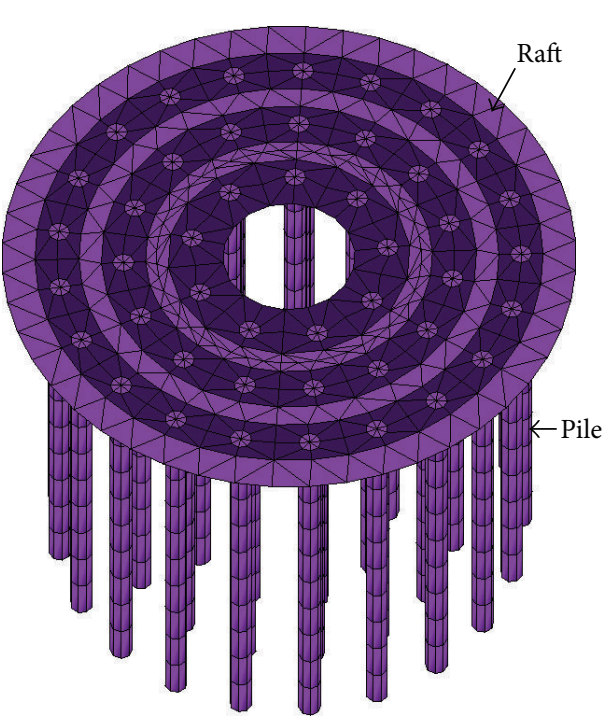

(a)

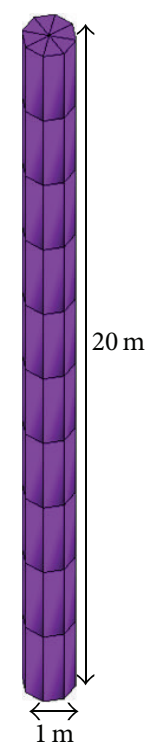

(b)

FIGURE 3: Finite element model of (a) piled raft foundation and (b) pile.

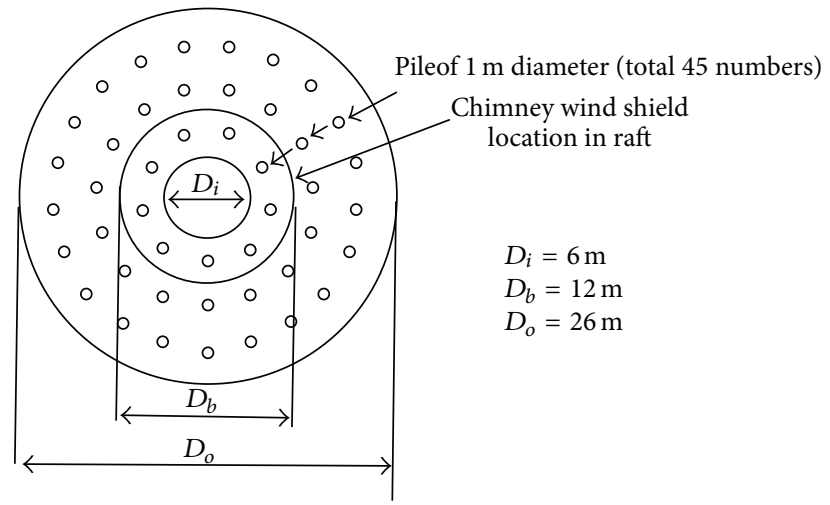

Figure 4: Plan view of raft of piled raft foundation of $200 \mathrm{~m}$ chimney.

where $v_{p}$ and $v_{s}$ are the dilatational and shear wave velocity of the considered medium, $\rho$ is the density of soil medium, $A_{n}, A_{t 1}$, and $A_{t 2}$ are the fields controlling the viscous dampers, and the subscripts $n$ and $t$ represent normal and tangent directions in the boundary. The viscous boundary is equivalent to a series of dampers on artificial boundary to absorb wave energy. It is implemented in the finite element analysis by using spring-damper element of ANSYS software.

\section{Time History Analysis}

The time history analysis of the integrated SSI system was carried out for ground motion corresponding to the longitudinal component of Imperial Valley earthquake at El Centro (1940) with a magnitude of 7.0 and peak ground acceleration of $0.319 \mathrm{~g}$. The total duration of the ground motion taken is 30 seconds. Acceleration time history and associated fourier

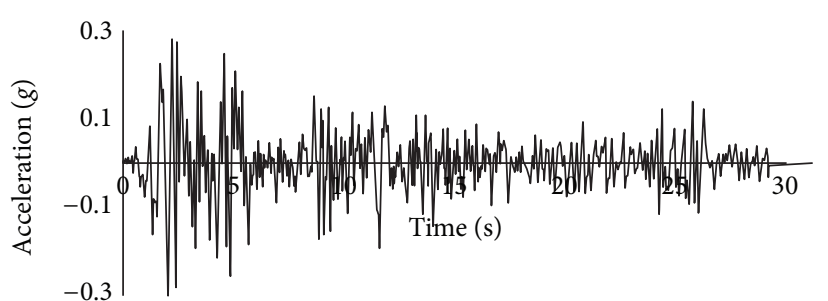

Figure 5: Time history plot of El Centro ground motion.

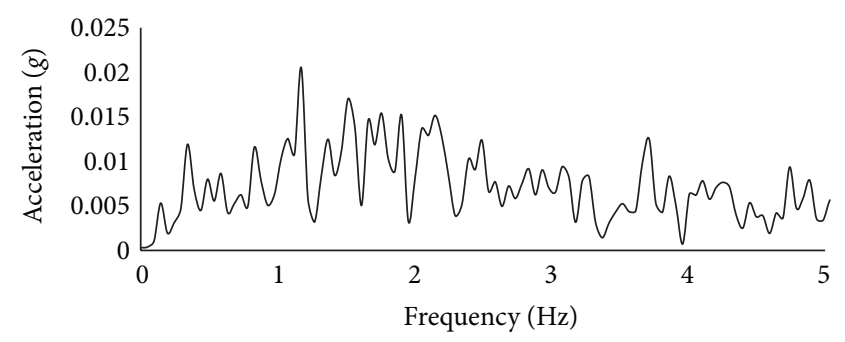

Figure 6: FFT plot of El Centro ground motion.

spectrum of this ground motion are shown in Figures 5 and 6 , respectively. The time history of acceleration was applied in the global $X$ direction of the integrated structure-foundationsoil model.

Damping is a function of frequency and Rayleigh damping is more appropriate for transient dynamic analysis. The Rayleigh damping is introduced through the coefficients $\alpha$ and $\beta$ which are used to form the damping matrix $[C]$ :

$$
\begin{gathered}
{[C]=\alpha[M]+\beta[K]} \\
\frac{\alpha}{2 \omega}+\frac{\beta \omega}{2}=\zeta,
\end{gathered}
$$

where $\omega$ is the natural frequency of the SSI system and $\zeta$ is the damping ratio and it is expressed as a percentage of critical damping. In the present study, the damping ratio equivalent to $5 \%$ of critical damping is assumed as structural damping as per the previous dynamic soil-structure interaction studies $[34,35]$. The horizontal loading due to wind and other causes were neglected.

The responses in annular raft of piled raft foundation of chimney founded on flexible base obtained from finite element analysis were compared with that of rigid base obtained from conventional analysis. The variation of responses in annular raft due to the effect of flexibility of soil, effect of thickness of raft, and effect of frequency content in the ground motion is studied.

\section{Results and Discussion}

The three-dimensional seismic SSI analysis was conducted for RC chimneys with piled raft foundation. The effect of SSI was studied by considering four different soil types with respect to the geotechnical characteristic and three different ratios of outer diameter to thickness of raft. The significance of characteristics of the ground motion was also 
studied. The responses in terms of tangential and radial bending moment and settlement of raft of piled raft were evaluated from the finite element analysis. The absolute maximum response of tangential and radial bending moment and settlement of annular raft were considered from their response time histories. The tangential and radial bending moment in the raft of piled raft obtained from SSI analysis was compared with that obtained from the conventional analysis considering rigidity at the base of the raft foundation. The bending moments evaluated from conventional method are designated as IS11089 in graphs and tables.

6.1. Effect of Stiffness of Soil. Four types of soils were selected, namely S1, S2, S3, and S4 which represent loose sand, medium sand, dense sand, and rock, respectively, in order to understand the effect of SSI on the tangential and radial bending moment in raft as well as the settlement of the raft of piled raft foundation.

6.1.1. Variation in Tangential Moment in Raft. Effect of stiffness of soil on the tangential moments in raft of piled raft foundation was evaluated. The tangential moment in raft of piled raft obtained from SSI analysis was compared with that obtained from conventional analysis as per IS:11089-1984. The representative graphs for tangential moments at various radial locations from inner to outer edge of the raft of $100 \mathrm{~m}$, $200 \mathrm{~m}$, and $400 \mathrm{~m}$ chimneys are shown in Figure 7.

It is found that the maximum tangential moment in raft is obtained at inner edge of the raft and it decreases towards the outer edge of the raft from conventional analysis of annular raft foundation. From the three-dimensional seismic analysis of integrated chimney-piled raft soil system, it is seen that the maximum tangential moment in raft is obtained at the chimney shell location $(r / a=0.43$ for $H=100 \mathrm{~m}, r / a=0.46$ for $H=200 \mathrm{~m}$ and $r / a=0.40$ for $H=400 \mathrm{~m}$ ) in the raft. The effect of pile group on the raft is clearly visible from the moment response in raft of $400 \mathrm{~m}$ chimney as there is a sudden variation of moment at the pile locations in the raft. In the case of $100 \mathrm{~m}$ chimney, the effect of pile group on the moment response in raft is comparatively less as compared to that in $400 \mathrm{~m}$ chimney.

It is well clear that the tangential moment increases with the decrease in stiffness of soil. This may be due to the fact that the raft of piled raft foundation behaves as a rigid plate when the structure interacts with loose sand. The time history plot of tangential moment in raft at chimney windshield location of $100 \mathrm{~m}$ chimney $\left(D_{o} / t=12.5\right)$ is shown in Figure 8. It is found that the absolute maximum moment response in raft is obtained at $4.56 \mathrm{~s}, 4.42 \mathrm{~s}, 4.38 \mathrm{~s}$, and $4.36 \mathrm{~s}$ for the raft $\left(D_{o} / t=\right.$ 12.5 and $H=100 \mathrm{~m}$ ) that interacts with soil types S1, S2, S3, and $\mathrm{S} 4$, respectively.

The maximum tangential moment obtained from conventional analysis and SSI analysis is given in Table 4. It is observed that the maximum tangential moment obtained from the conventional analysis is more than that obtained from the SSI analysis. The decrease in variation of tangential moment in raft of flexible base from that of rigid base is more

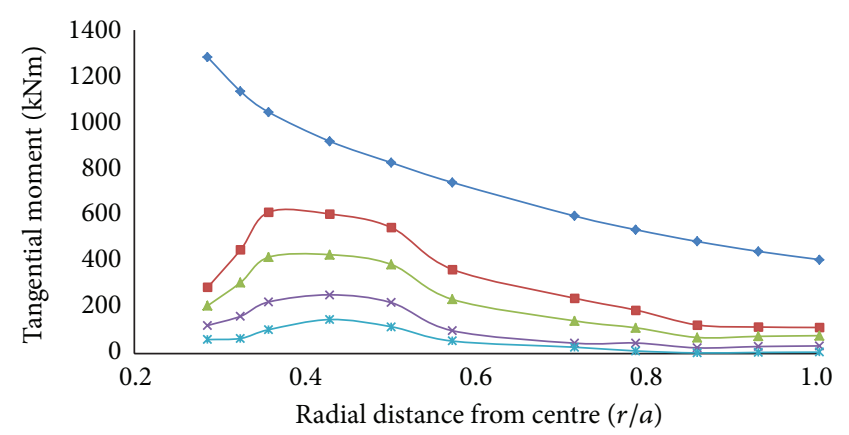

(a)

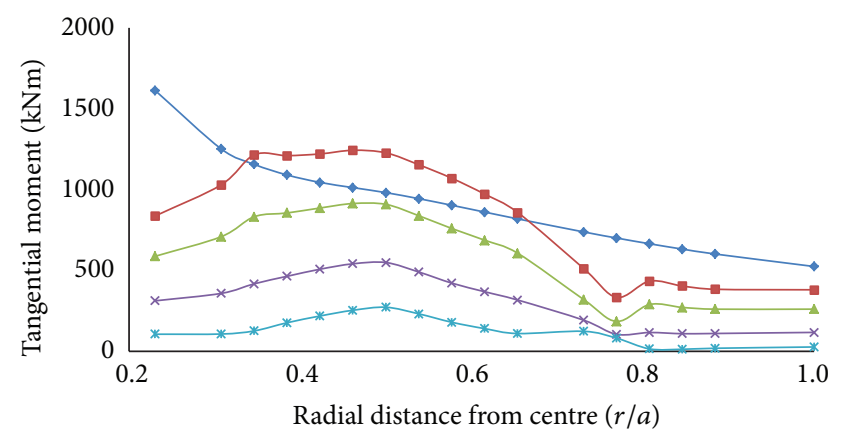

(b)

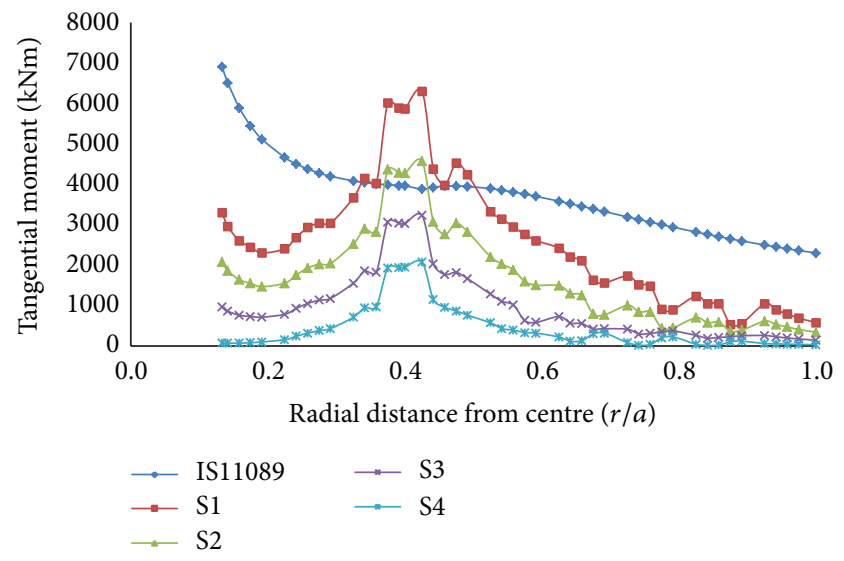

(c)

Figure 7: Tangential moment in raft $\left(D_{o} / t=12.5\right)$ of (a) $100 \mathrm{~m}$ (b) $200 \mathrm{~m}$, and (c) $400 \mathrm{~m}$ chimney.

for $100 \mathrm{~m}$ chimney compared to that in $200 \mathrm{~m}$ and $400 \mathrm{~m}$ chimneys.

6.1.2. Variation in Radial Moment in Raft. The radial moment response in annular raft of piled raft foundation is studied due to that the effect of flexibility of soil is studied. The radial moment in raft is also evaluated from conventional analysis. The representative graphs for radial moments at various radial locations from inner to outer edge of the raft of $100 \mathrm{~m}, 200 \mathrm{~m}$, and $400 \mathrm{~m}$ chimneys are shown in Figure 9. Like conventional analysis, the SSI analysis also shows the maximum moment at chimney windshield location in raft. It is also found that the radial moment in raft decreases with 
TABLE 4: Percentage variation of maximum tangential moment.

\begin{tabular}{|c|c|c|c|c|c|}
\hline \multirow{2}{*}{$H(\mathrm{~m})$} & \multirow{2}{*}{ Maximum tangential moment as per IS11089 $(\mathrm{kNm})$} & \multirow{2}{*}{ Soil type } & \multicolumn{3}{|c|}{ Percentage variation of maximum tangential moment (\%) } \\
\hline & & & $D_{o} / t=12.5$ & $D_{o} / t=17.5$ & $D_{o} / t=22.5$ \\
\hline \multirow{4}{*}{100} & \multirow{4}{*}{1281.54} & S1 & -52.22 & -71.29 & -83.56 \\
\hline & & S2 & -66.61 & -82.61 & -90.73 \\
\hline & & S3 & -80.17 & -90.32 & -94.63 \\
\hline & & S4 & -88.5 & -93.45 & -95.62 \\
\hline \multirow{4}{*}{200} & \multirow{4}{*}{1611.1} & S1 & -22.88 & -47.74 & -64.5 \\
\hline & & S2 & -43.3 & -67.17 & -79.3 \\
\hline & & S3 & -65.94 & -82.57 & -89.58 \\
\hline & & S4 & -83.09 & -91.97 & -95.47 \\
\hline \multirow{4}{*}{400} & \multirow{4}{*}{6905.15} & $\mathrm{~S} 1$ & -8.78 & -32.12 & -47.74 \\
\hline & & S2 & -33.8 & -53.97 & -65.15 \\
\hline & & S3 & -53.28 & -68.94 & -76.5 \\
\hline & & S4 & -69.97 & -80.37 & -85.42 \\
\hline
\end{tabular}

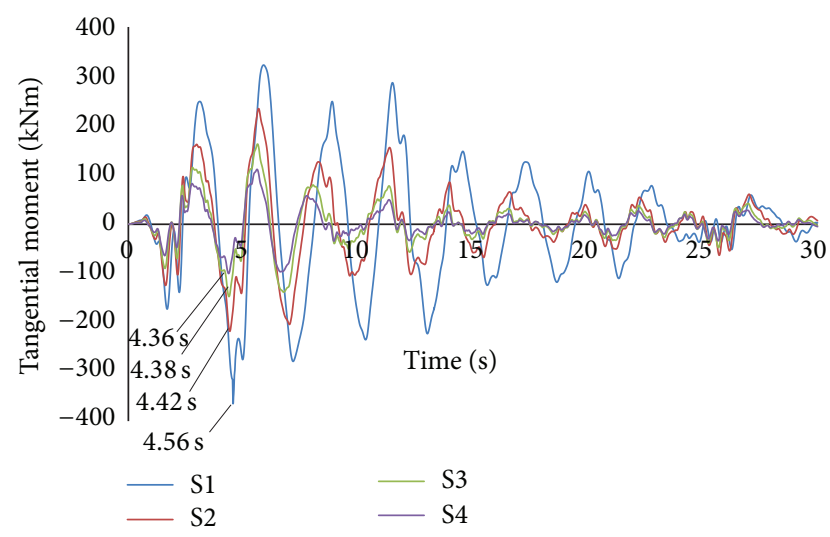

FIgURE 8: Time history plot of tangential moment in raft of $100 \mathrm{~m}$ chimney $\left(D_{o} / t=12.5\right)$.

the increase in stiffness of soil. Raft behaves as flexible plate when it is founded on very stiff soil. Moment sharing by the piles is seen as a sudden variation of moment in raft at the location of piles.

The time history plot of radial moment in raft at chimney windshield location of $100 \mathrm{~m}$ chimney $\left(D_{o} / t=12.5\right)$ is shown in Figure 10. The absolute maximum radial moment response in raft is obtained at different times when the chimney-raftsoil system interacts with different types of soil. The absolute maximum radial and tangential moments in raft occurred at $4.56 \mathrm{~s}, 4.42 \mathrm{~s}, 4.38 \mathrm{~s}$, and $4.36 \mathrm{~s}$ for chimney with foundation $\left(D_{o} / t=12.5\right)$ resting on soil types S1, S2, S3, and S4, respectively.

Table 5 presents the maximum radial moments obtained from both conventional analysis and SSI analysis. It is found that the maximum radial moment in raft $\left(D_{o} / t=12.5\right)$ obtained from SSI analysis is more than that obtained from conventional analysis for the $100 \mathrm{~m}$ chimney founded on soil types S1 and S2. The radial moment in raft of $200 \mathrm{~m}$ chimney resting on all soil types shows higher values than that obtained from conventional analysis. In the case of $400 \mathrm{~m}$ chimney, it is seen that the maximum moment obtained from conventional analysis is more than that obtained from the SSI analysis. Therefore it is clear that unlike tangential moment, the effect of SSI is more in the case of radial moment response than in raft of chimney. The maximum increase in radial moment in raft is observed for $200 \mathrm{~m}$ chimney $\left(D_{o} / t=12.5\right)$ and the percentage variations of moments are $244.32 \%, 182.84 \%, 109.69 \%$, and $44.01 \%$, respectively, for chimney resting on the soil types S1, S2, S3, and S4 from the conventional analysis.

6.1.3. Variation in Settlement of Raft. The representative diagrams of the settlement of raft $\left(D_{o} / t=12.5\right)$ of $100 \mathrm{~m}$, $200 \mathrm{~m}$, and $400 \mathrm{~m}$ chimneys at various radial locations from inner to outer edge along the centre of the raft are shown in Figure 11. It is seen that as the soil type is varied from S4 to S1, that is, from rock to loose sand, the settlement of the raft increases. The soil deformation is negligible for the stiff soil type S4. The settlement pattern shows that the maximum settlement is obtained at chimney windshield location in the raft and it decreases towards the outer edge of the raft when the chimney with the foundation rests on soil types S2, S3, and S4. The same settlement pattern is observed for the raft of $400 \mathrm{~m}$ chimney founded on soil type S1. The settlement of raft of shorter chimneys $(H=100 \mathrm{~m} \& 200 \mathrm{~m})$ founded on loose sand shows the maximum settlement at the outer edge of raft.

The absolute maximum settlement of raft $\left(D_{o} / t=12.5\right)$ of $100 \mathrm{~m}$ chimney founded on soil type $\mathrm{S} 1$ shows the maximum value at the outer edge and it occurred at $5.82 \mathrm{~s}$ during the ground motion. The absolute maximum settlement of raft of same chimney resting on soil types S2, S3, and S4 occurred at the chimney windshield location in raft at $5.66 \mathrm{~s}, 5.62 \mathrm{~s}$, and $5.60 \mathrm{~s}$, respectively, during the ground motion. It is found that the maximum absolute settlement of raft and the maximum absolute bending moment in raft are obtained at different times from the time history analysis of chimney-piled raftsoil system. The maximum settlement of raft of piled-raft foundation is tabulated in Table 6 . The maximum settlement 


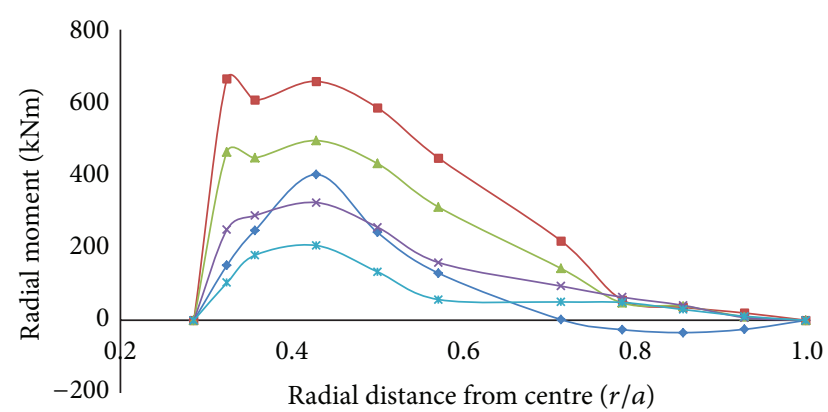

(a)

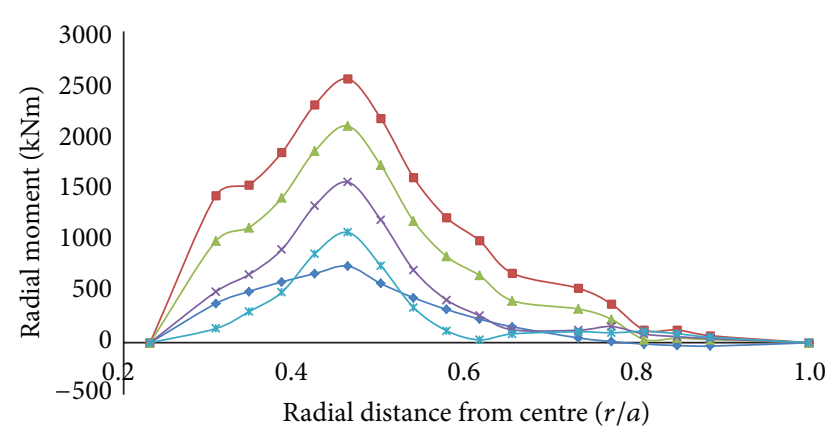

(b)

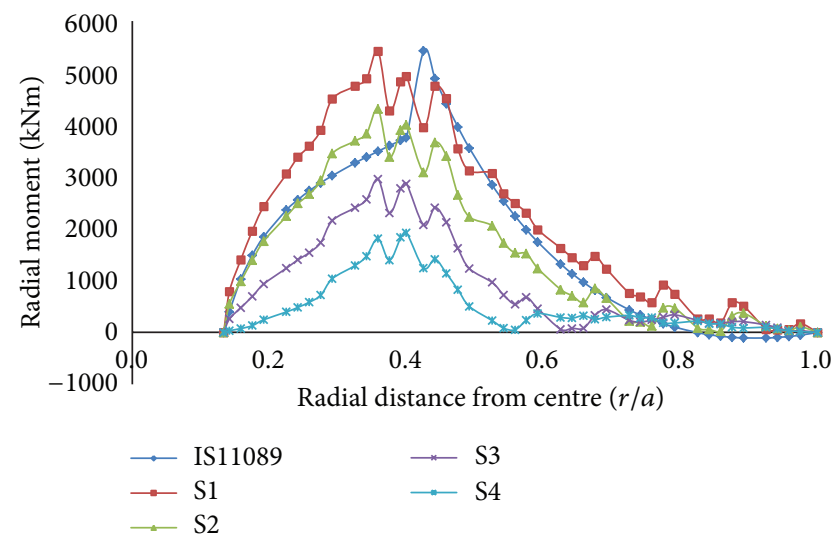

(c)

Figure 9: Radial moment in raft $\left(D_{o} / t=12.5\right)$ of (a) $100 \mathrm{~m}$ (b) $200 \mathrm{~m}$, and (c) $400 \mathrm{~m}$ chimney.

of raft is observed for $400 \mathrm{~m}$ chimney supported on raft $\left(D_{o} / t=22.5\right)$ of piled foundation resting on soil type S1.

6.2. Effect of Stiffness of Raft. The effect of thickness of the raft was investigated by considering three different ratios of diameter to thickness $\left(D_{o} / t\right)$ of the raft and the ratios are 12.5, 17.5 and 22.5. It is found that the bending moments in raft of piled raft obtained from SSI analysis increases with decrease in $D_{o} / t$ ratio. This is because of high structural rigidity of the raft of piled raft foundation of chimney for lower $D_{o} / t$ ratios.

A decrease in the variation of bending moment in raft of flexible base from that of rigid base, with respect to increase in the $D_{o} / t$ ratio is also seen. The variations are found more in chimney-foundation system resting on soil type S1. From the SSI analysis, it is observed that the tangential moment

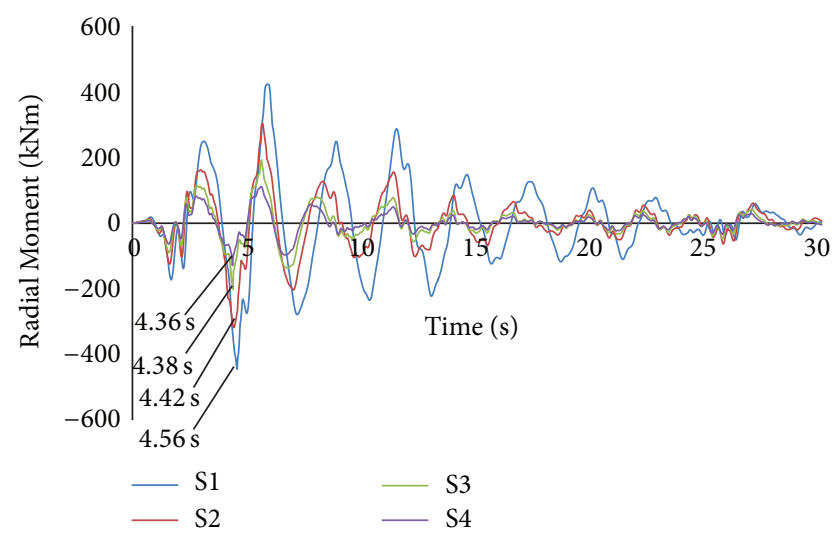

FIGURE 10: Time history plot of tangential moment in raft of $100 \mathrm{~m}$ chimney $\left(D_{o} / t=12.5\right)$.

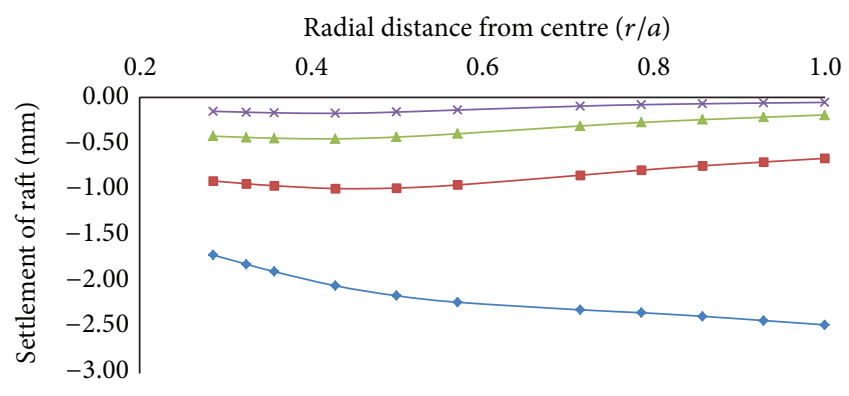

(a)

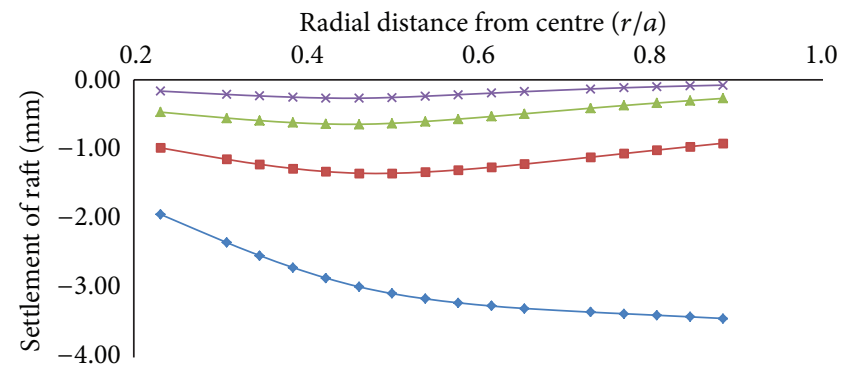

(b)

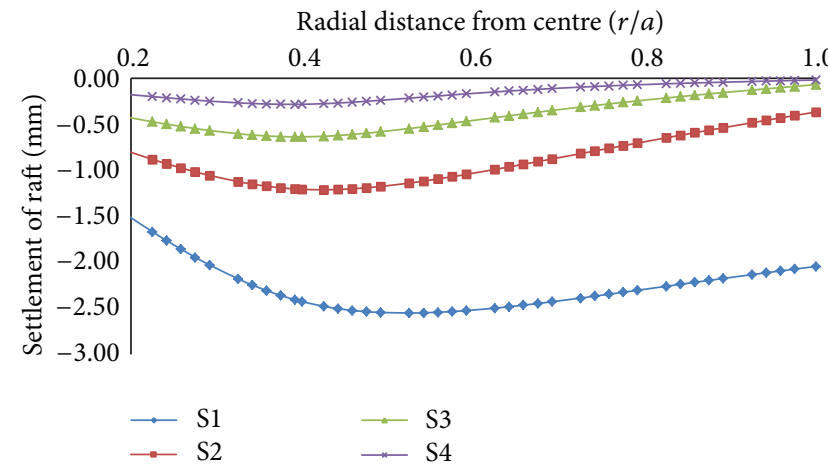

(c)

FIGURE 11: Settlement in raft $\left(D_{o} / t=12.5\right)$ of (a) $100 \mathrm{~m}$ (b) $200 \mathrm{~m}$ and (c) $400 \mathrm{~m}$ chimney. 
TABLE 5: Percentage variation of maximum radial moment.

\begin{tabular}{|c|c|c|c|c|c|}
\hline \multirow{2}{*}{$H(\mathrm{~m})$} & \multirow{2}{*}{ Maximum radial moment as per IS11089 $(\mathrm{kNm})$} & \multirow{2}{*}{ Soil type } & \multicolumn{3}{|c|}{ Percentage variation of maximum radial moment (\%) } \\
\hline & & & $D_{o} / t=12.5$ & $D_{o} / t=17.5$ & $D_{o} / t=22.5$ \\
\hline \multirow{4}{*}{100} & \multirow{4}{*}{401.096} & S1 & 65.51 & 11.34 & -25.81 \\
\hline & & S2 & 23.27 & -22.45 & -48.21 \\
\hline & & S3 & -19.26 & -49.84 & -65.69 \\
\hline & & S4 & -48.71 & -68.15 & -79.55 \\
\hline \multirow{4}{*}{200} & \multirow{4}{*}{737.951} & S1 & 244.32 & 162.38 & 105.02 \\
\hline & & S2 & 182.84 & 106.1 & 64.55 \\
\hline & & S3 & 109.69 & 51.34 & 21.58 \\
\hline & & S4 & 44.01 & 0.61 & -22.66 \\
\hline \multirow{4}{*}{400} & \multirow{4}{*}{5424.34} & S1 & -0.12 & -28.8 & -53.59 \\
\hline & & S2 & -20.74 & -48.04 & -62.07 \\
\hline & & S3 & -45.54 & -64.38 & -72.78 \\
\hline & & S4 & -64.62 & -76.07 & -81.66 \\
\hline
\end{tabular}

TABLE 6: Maximum settlement of raft.

\begin{tabular}{ccccc}
\hline \multirow{2}{*}{$H(\mathrm{~m})$} & \multirow{2}{*}{ Soil type } & \multicolumn{3}{c}{ Maximum settlement $(\mathrm{mm})$} \\
& & $D_{o} / t=12.5$ & $D_{o} / t=17.5$ & $D_{o} / t=22.5$ \\
\hline \multirow{4}{*}{100} & S1 & 2.47 & 2.73 & 3.16 \\
& S2 & 0.99 & 1.3 & 1.5 \\
& S3 & 0.45 & 0.54 & 0.63 \\
& S4 & 0.17 & 0.19 & 0.21 \\
\hline \multirow{4}{*}{400} & S1 & 3.44 & 3.8 & 4.3 \\
& S2 & 1.34 & 1.77 & 2.03 \\
& S3 & 0.64 & 0.79 & 0.89 \\
& S4 & 0.26 & 0.31 & 0.35 \\
\hline \multirow{4}{*}{400} & S1 & 2.55 & 3.61 & 4.47 \\
& S2 & 1.21 & 1.76 & 2.12 \\
& S3 & 0.64 & 0.84 & 0.97 \\
& S4 & 0.28 & 0.35 & 0.39 \\
\hline
\end{tabular}

in raft decreases in the range of $20-25 \%$ as the thickness of raft reduces from $D_{o} / t=12.5$ to $D_{o} / t=17.5$ for all chimneys resting on soil type $S 1$. The tangential moment of raft of $D_{o} / t=22.5$ reduces from that of $D_{o} / t=12.5$ by 31$39 \%$.

In the case of variation of radial moment, the maximum variation is seen for $200 \mathrm{~m}$ chimney resting on soil type S1. Here the reduction is $81.94 \%$ and $139.3 \%$ respectively for rafts with $D_{o} / t$ ratio of 17.5 and 22.5 from that of $D_{o} / t=12.5$ showing considerable effect of stiffness of the foundation. Similarly, the variation among the rafts with $D_{o} / t$ ratio of 17.5 and 22.5 from that of $D_{o} / t=12.5$ is $54.16 \% \& 91.32 \%$ for $100 \mathrm{~m}$ chimney and $28.68 \%$ \& $53.47 \%$ for $400 \mathrm{~m}$ chimney respectively.

The settlement of raft increases with increase in the $D_{o} / t$ ratio. The maximum variation of settlement in raft with $D_{o} / t$ ratio of 17.5 and 22.5 from that of $D_{o} / t=12.5$ is $41.56 \%$ and $75.29 \%$ respectively for $400 \mathrm{~m}$ chimney.
6.3. Effect of Frequency Content in the Ground Motion. The effect of characteristics of the ground motion on bending moment response in raft is assessed. The fundamental natural frequency ranges from $0.365 \mathrm{~Hz}$ to $0.424 \mathrm{~Hz}$ for $100 \mathrm{~m}$ high chimney-piled raft-soil system. It ranges from $0.213 \mathrm{~Hz}$ to $0.25 \mathrm{~Hz}$ and from $0.126 \mathrm{~Hz}$ to $0.143 \mathrm{~Hz}$, respectively, for SSI system of $200 \mathrm{~m}$ chimney and $400 \mathrm{~m}$ chimney. From the FFT plot of the El Centro ground motion (Figure 6), it is seen that the maximum amplitude lies at $1.17 \mathrm{~Hz}$ and there are no predominant frequency contents available in the range of fundamental natural frequencies of SSI system of $400 \mathrm{~m}$ chimney. It is also noted that there is not much peak amplitude frequency content which lies in the range of fundamental natural frequency of $200 \mathrm{~m}$ high chimney-piled raft-soil system, but there are some higher peaks in amplitude corresponding to frequencies of third mode $(1.07 \mathrm{~Hz}-$ $1.23 \mathrm{~Hz}$ ) of this SSI system. Some high amplitude frequency contents exist in the range of fundamental frequencies of SSI system of $100 \mathrm{~m}$ chimney. From the radial bending moment response in raft, it is seen that the effect of seismic SSI is more suitable for the $200 \mathrm{~m}$ chimney than to other chimneys due to the contribution from the third mode response. Therefore, the radial moment response in raft of piled raft of $200 \mathrm{~m}$ chimney with flexible base is high.

From the SSI analysis, the maximum settlements of raft of $100 \mathrm{~m}, 200 \mathrm{~m}$, and $400 \mathrm{~m}$ chimneys are $3.16 \mathrm{~mm}, 4.3 \mathrm{~mm}$ and $4.47 \mathrm{~mm}$, respectively. These maximum settlements are obtained for thinner rafts of $D_{o} / t=22.5$ resting on loose sand. It is obvious that the settlement of raft increases with increase in height of chimney due to the self-weight of the structure. It is also noticed that the maximum settlement of the raft $\left(D_{o} / t=12.5\right)$ of $200 \mathrm{~m}$ chimney is more than that of $400 \mathrm{~m}$ chimney for all soil cases and this is due to the significant contribution from the higher mode participation in the response. It clearly indicates the significance of structural geometry and characteristics of ground motion in determining the response in the raft of chimney-piled raftsoil system. 


\section{Conclusions}

The effect of SSI is studied for tall reinforced concrete chimneys with piled raft foundation subjected to El Centro (1940) ground motion. The material properties of the soil and geometric properties of the chimney and raft of piled raft foundation were varied to understand the significance of SSI. The responses such as radial and tangential bending moment in raft and settlement of raft were considered for study. The absolute maximum bending moment in raft from SSI analysis is compared with that obtained from conventional analysis. study.

The following conclusions are drawn from the present

(i) The tangential moment in raft obtained from the dynamic SSI analysis is less than that obtained from the conventional analysis.

(ii) The pattern of tangential moments in the raft obtained from the three-dimensional dynamic SSI analysis and that obtained from conventional analysis are different.

(iii) The effect of SSI is more on the radial moment of raft of piled raft foundation of chimney.

(iv) The dynamic SSI effect is more prominent in $100 \mathrm{~m}$ and $200 \mathrm{~m}$ chimney as compared to $400 \mathrm{~m}$ chimney.

(v) The higher modes of SSI system are also significant in determining the response in the raft.

\section{Conflict of Interests}

The authors declare that they have no conflict of interests.

\section{References}

[1] I. Caliò, A. Greco, and A. Santini, "Simplified dynamic analysis of pile-soil-structure interaction," in Proceedings of the 18th GIMC Conference Siracusa, September 2010.

[2] B. K. Maheshwari, K. Z. Truman, M. H. El Naggar, and P. L. Gould, "Three-dimensional nonlinear analysis for seismic soil-pile-structure interaction," Soil Dynamics and Earthquake Engineering, vol. 24, no. 4, pp. 343-356, 2004.

[3] H. Tahghighi and K. Konagai, "Numerical analysis of nonlinear soil-pile group interaction under lateral loads," Soil Dynamics and Earthquake Engineering, vol. 27, no. 5, pp. 463-474, 2007.

[4] K. Yamashita, J. Hamada, and S. Onimaru, "Masahiko Higashino Seismic behavior of piled raft with ground improvement supporting a base-isolated building on soft ground in Tokyo," Soils and Foundations, vol. 52, no. 5, pp. 1000-1015, 2012.

[5] H. G. Poulos and E. H. Davis, Elastic Solutions for Soil and Rock Mechanics, John Wiley \& Sons, New York, NY, USA, 1974.

[6] W. G. K. Fleming, A. J. Weltman, M. F. Randolph, and W. K. Elson, Piling Engineering, Surrey University Press, London, UK, 2nd edition, 1992.

[7] M. F. Randolph, "Design methods for pile groups and piled rafts," in Proceedings of the 13th International Conference on Soil Mechanics and Foundation Engineering, vol. 5, pp. 61-82, New Delhi, India, 1994.

[8] L. D. Ta and J. C. Small, "An approximation for analysis of raft and piled raft foundations," Computers and Geotechnics, vol. 20, no. 2, pp. 105-123, 1997.
[9] D. G. Lin and Z. Y. Feng, "A numerical study of piled raft foundations," Journal of the Chinese Institute of Engineers, vol. 29, no. 6, pp. 1091-1097, 2006.

[10] Z. Y. Ai and Y. C. Cheng, "Analysis of vertically loaded piles in multilayered transversely isotropic soils by BEM," Engineering Analysis with Boundary Elements, vol. 37, no. 2, pp. 327-335, 2013.

[11] D. D. C. Nguyen, S. B. Jo, and D. S. Kim, "Design method of piled-raft foundations under vertical load considering interaction effects," Computers and Geotechnics, vol. 47, pp. 16-27, 2013.

[12] E. Bourgeois, P. Buhan, and G. Hassen, "Settlement analysis of piled-raft foundations by means of a multiphase model accounting for soil-pile interactions," Computers and Geotechnics, vol. 46, pp. 26-38, 2012.

[13] M. Huang, F. Liang, and J. Jiang, "A simplified nonlinear analysis method for piled raft foundation in layered soils under vertical loading," Computers and Geotechnics, vol. 38, no. 7, pp. 875-882, 2011.

[14] J. H. Lee, Y. Kim, and S. Jeong, “Three-dimensional analysis of bearing behavior of piled raft on soft clay," Computers and Geotechnics, vol. 37, no. 1-2, pp. 103-114, 2010.

[15] E. M. Comodromos, M. C. Papadopoulou, and I. K. Rentzeperis, "Pile foundation analysis and design using experimental data and 3-D numerical analysis," Computers and Geotechnics, vol. 36, no. 5, pp. 819-836, 2009.

[16] M. T. A. Chaudhary, "FEM modelling of a large piled raft for settlement control in weak rock," Engineering Structures, vol. 29, no. 11, pp. 2901-2907, 2007.

[17] J. P. Wolf, Dynamic Soil-Structure Interaction, Prentice Hall, New York, NY, USA, 1985.

[18] A. Burman, P. Nayak, P. Agrawal, and D. Maity, "Coupled gravity dam-foundation analysis using a simplified direct method of soil-structure interaction," Soil Dynamics and Earthquake Engineering, vol. 34, no. 1, pp. 62-68, 2012.

[19] H. R. Tabatabaiefar and A. Massumi, "A simplified method to determine seismic responses of reinforced concrete moment resisting building frames under influence of soil-structure interaction," Soil Dynamics and Earthquake Engineering, vol. 30, no. 11, pp. 1259-1267, 2010.

[20] A. Gouasmia, K. Djeghaba, and M. Merzoud, "Direct approach to seismic soil-structure-interaction analysis: building group case," International Review of Mechanical Engineering, vol. 3, no. 5, pp. 679-686, 2009.

[21] K. Baba, K. Park, and N. Ogava, "Soil-Structure Interaction Systems on the base of the ground impedance functions formed in to a chain of impulses along the time axis," in Proceedings of the 11th World Conference on Earthquake Engineering, Acapulco, Mexico, 1996.

[22] J. P. Wolf and C. Song, "Some cornerstones of dynamic soilstructure interaction," Engineering Structures, vol. 24, no. 1, pp. 13-28, 2002.

[23] A. S. Arya and D. K. Paul, "Earthquake response of tall chimneys," in Proceedings of the 6th World Conference, pp. 12471259, New Delhi, India, 1977.

[24] N. S. Pour and I. Chowdhury, "Dynamic soil structure interaction analysis of tall multi-flue chimneys under aerodynamic and seismic force," in Proceedings of the 12th International Conference of the International Association for Computer Methods and Advances in Geomechanics (IACMAG '08), pp. 2696-2703, Goa, India, 2008. 
[25] D. Mehta and N. J. Gandhi, "Time study response of tall chimneys, under the effect of soil structure interaction and long period earthquake impulse," in Proceedings of the 14th World Conference on Earthquake Engineering, Beijing, China, 2008.

[26] B. R. Jayalekshmi, D. Menon, and A. M. Prasad, "Effect of soilstructure interaction on along-wind response of tall chimneys," in Proceedings of the 13th International Conference of the International Association for Computer Methods and Advances in Geomechanics (IACMAG '11), pp. 846-851, 2011.

[27] H. van Koten, "Wind induced vibrations of chimneys: the rules of the CICIND code for steel chimneys," Engineering Structures, vol. 6, no. 4, pp. 350-356, 1984.

[28] IS:11089-1984, "Code of practice for design and construction of ring foundation," Bureau of Indian Standards, New Delhi, India.

[29] D. Menon and P. S. Rao, "Estimation of along-wind moments in RC chimneys," Engineering Structures, vol. 19, no. 1, pp. 7178, 1997.

[30] J. E. Bowles, Foundation Analysis and Design, McGraw-Hill International Editions, Singapore, 1997.

[31] NEHRP, "Recommended provisions for seismic regulations of new buildings," Part 1, provisions, FEMA 222A, 1994.

[32] H. Y. Fang, Foundation Engineering Handbook, Van Nostrand Reinhold, New York, NY, USA, 1991.

[33] IS:4998 (Part 1)-1992 (Reaffirmed 2003), "Criteria for the design of reinforced concrete chimneys," Bureau of Indian Standards, New Delhi, India.

[34] T. Cakir, "Evaluation of the effect of earthquake frequency content on seismic behaviour of cantilever retaining wall including soil-structure interaction," Soil Dynamics and Earthquake Engineering, vol. 45, pp. 96-111, 2013.

[35] M. R. Kianoush and A. R. Ghaemmaghami, "The effect of earthquake frequency content on the seismic behavior of concrete rectangular liquid tanks using the finite element method incorporating soil-structure interaction," Engineering Structures, vol. 33, no. 7, pp. 2186-2200, 2011. 

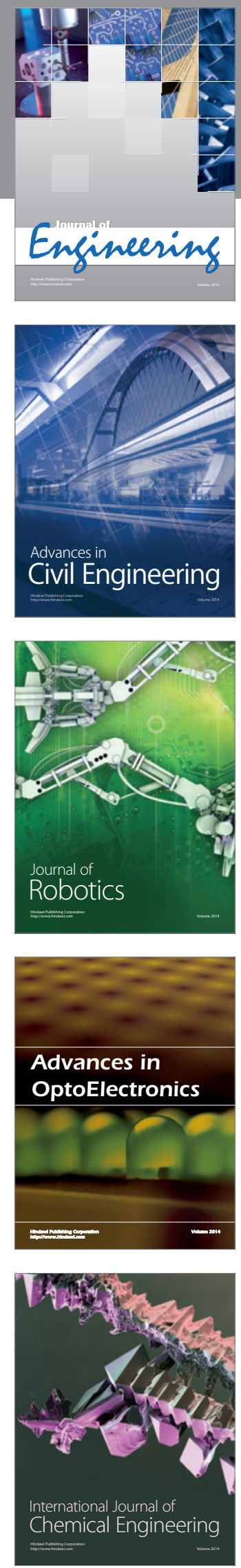

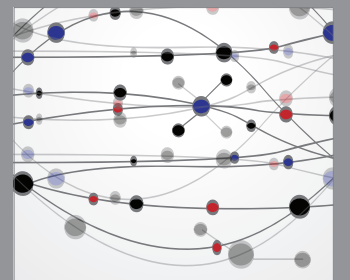

The Scientific World Journal
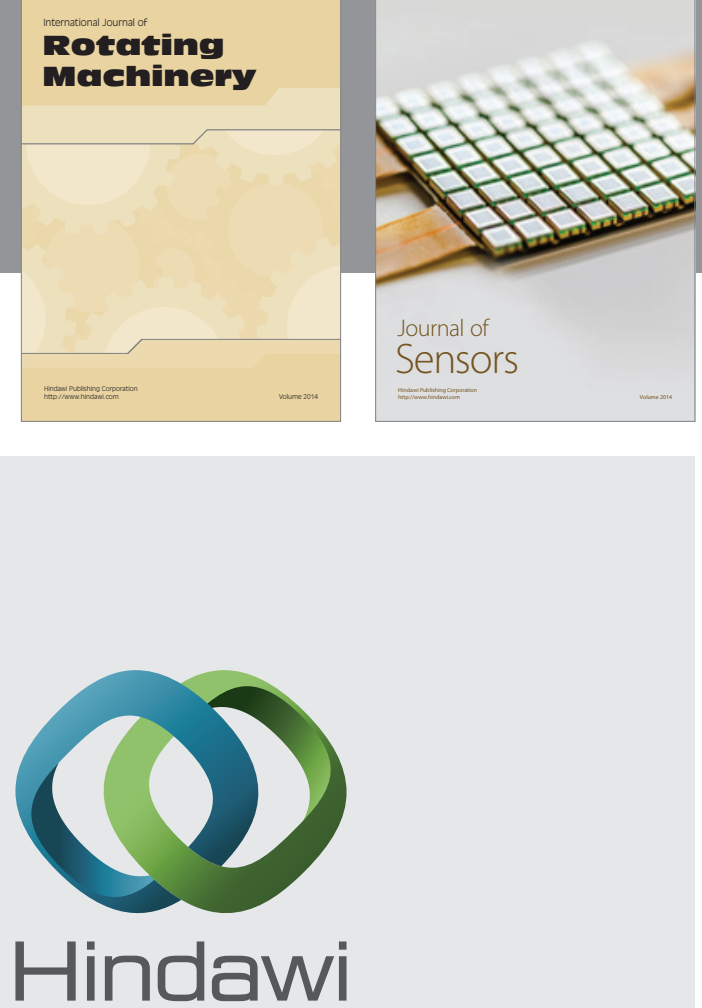

Submit your manuscripts at http://www.hindawi.com
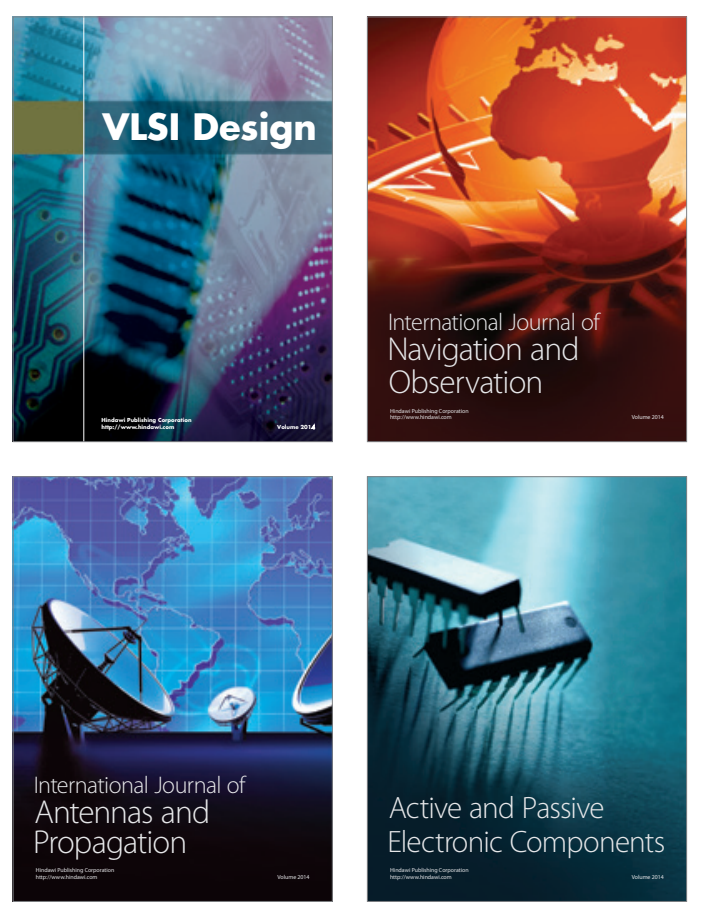
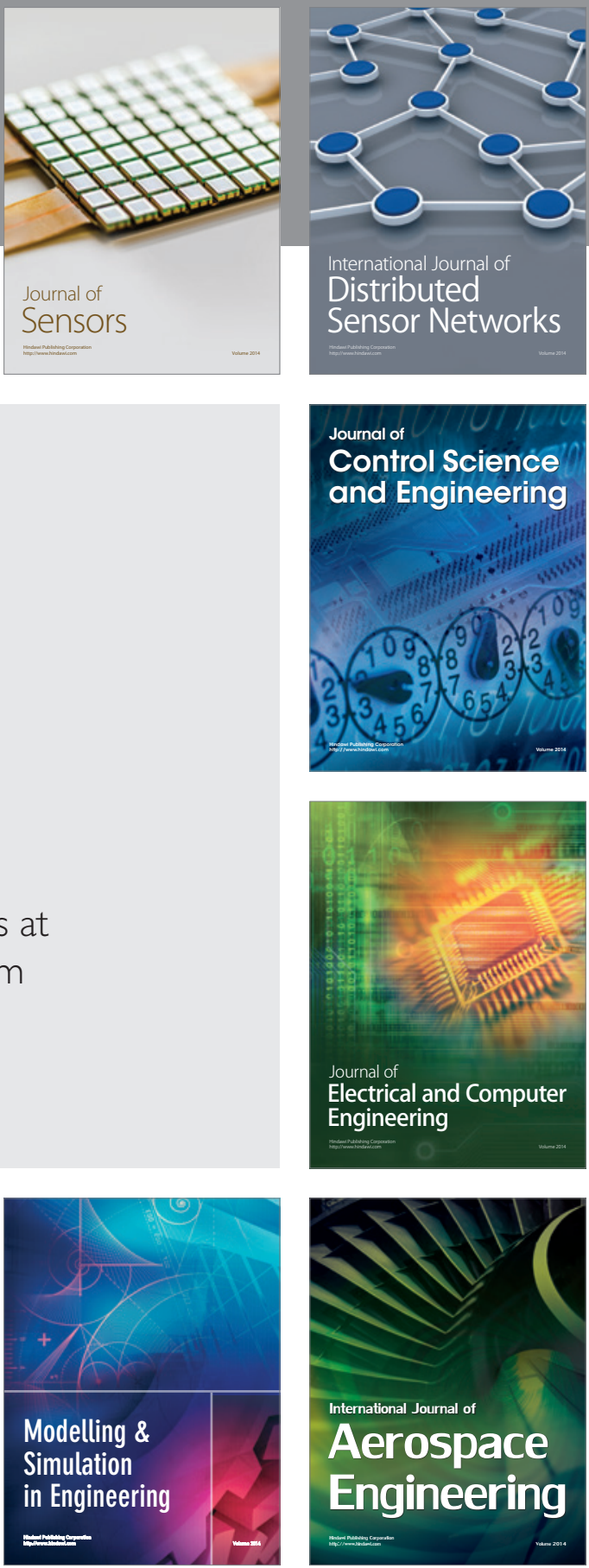

Journal of

Control Science

and Engineering
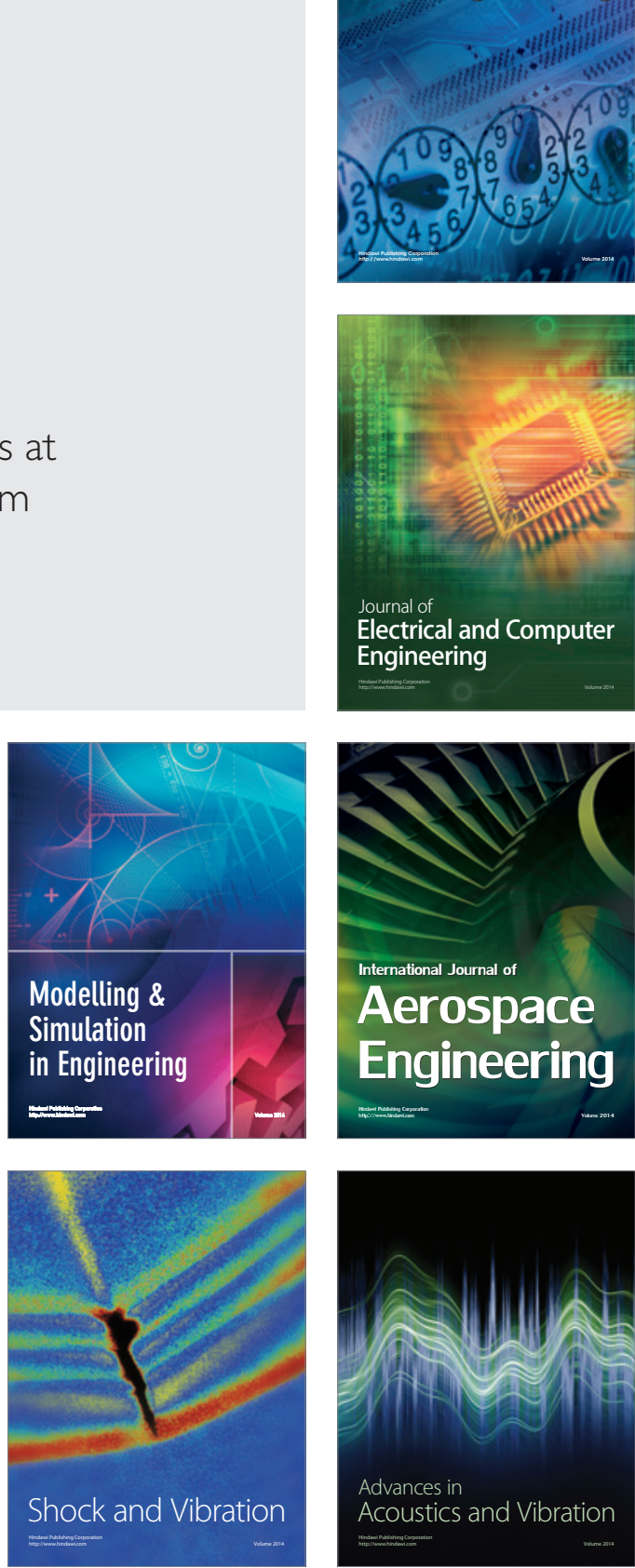